\title{
Effect of various plant growth regulators on yield and quality of guava (Psidium guajava L.) cv. LUCKNOW-49
}

\author{
R.P. RAJPUT, H.J. SENJALIYA*, G.S. VALA AND G.S. MANGROLIYA \\ Agriculture Research Station, (J.A.U.), Mahuva, SURAT (GUJARAT) INDIA(Email : hjpatel25@gmail.com)
}

\begin{abstract}
The present investigation was carried out to determine the suitable and optimum concentration of boron and plant growth regulators for maximum productivity and quality of guava cv. LUCKNOW-49 during Kharif season. From the present study it can be concluded that the treatment $\mathrm{T}_{10}\left(0.2 \%\right.$ boron $+\mathrm{GA}_{3} 60 \mathrm{ppm}+\mathrm{NAA} 150 \mathrm{ppm}+$ ethrel $\left.750 \mathrm{ppm}\right)$ was found best for physical parameters and treatment $\mathrm{T}_{5}(0.2 \%$ boron + NAA $150 \mathrm{ppm})$ for yield point of view, while for quality point of view the treatment $\mathrm{T}_{9}(0.2 \%$ boron + ethrel $1000 \mathrm{ppm})$ was found best. As far as the relative economics of the treatment is concerned, the maximum net realization of Rs. 1,72,807 per hectare with highest 1:6.6 cost benefit ratio $(\mathrm{CBR})$ was obtained by the treatment $\mathrm{T}_{5}(0.2 \%$ boron + NAA $150 \mathrm{ppm})$ as compared to other treatments. Therefore, the treatment $\mathrm{T}_{5}(0.2 \%$ boron + NAA $150 \mathrm{ppm})$ is best among all treatment for higher production.
\end{abstract}

Key Words : Guava (Psidium guajava L.), Boron, NAA, Ethrel yield, Quality

View Point Article : Rajput, R.P., Senjaliya, H.J., Vala, G.S. and Mangroliya, G.S. (2015). Effect of various plant growth regulators on yield and quality of guava (Psidium guajava L.) cv. LuCKNOW-49. Internat. J. agric. Sci., 11 (1): 179-182.

Article History : Received : 14.11.2014; Revised : 09.12.2014; Accepted : 23.12.2014

\footnotetext{
* Author for correspondence
} 